\title{
Defining and Performing the Functions of Extension Mentors ${ }^{1}$
}

\author{
Amy Harder and Savanna Turner ${ }^{2}$
}

\section{Introduction}

This document provides UF/IFAS Extension faculty serving as formal mentors with information about the three primary functions of a mentor and guidance on how to perform those functions using a mentor calendar.

\section{Three Functions of Mentoring}

Mentoring in a professional environment is traditionally defined as junior employees receiving professional development and advice from a more senior employee (Raabe \& Beehr, 2003). Some of the early research and practice of mentoring relationships in the workplace stems from Kram's (1983) work on the phases of the mentor relationship. Mentor relationships have two phases, career development and psychosocial support, which are mutually beneficial to the protégé and mentor (Kram, 1983). Scandura and Ragins (1993) built upon the work of Kram (1983) to create a mentoring model focusing on three functions that lead to the success of a mentoring relationship: career development, psychosocial support, and role modeling.

Career development can encourage a protégés performance, show mentees structures within an organization, and prepare them for advancement opportunities (Scandura \& Ragins, 1993). Another important role of a mentor is to be able and willing to place a protégé in important or challenging assignments that will assist in the professional growth of the protégé (Raabe \& Beehr, 2003). Some examples from the study conducted by Scandura and Ragins (1993) were "[my] mentor takes a personal interest in my career" (p. 257) and "[my] mentor has devoted special time and consideration to my career" (p. 257). Mentors play an important role in the career development of a protégé. The willingness and efforts of the mentor on the relationship influences the success of the protégés career development.

Psychosocial support can take many forms, such as coaching, friendship, and acceptance, which can develop a protégés sense of confidence and competence in a position (Kram, 1983). Some examples are "I share personal problems with my mentor" (Scandura \& Ragins, 1993, p. 257 ) and "I consider my mentor to be a friend" (Scandura \& Ragins, 1993, p. 257). Socializing outside of work, discussing personal issues, and considering each other as friends play an important role in the psychosocial support of a mentoring relationship (Raabe \& Beehr, 2003).

Role modeling, the third mentoring factor, can be described as when a protégé models the effective work behaviors of the mentor (Scandura \& Ragins, 1993). Mentors must be aware of their behaviors and the possibility that their protégés may mimic them without the experience needed to judge if the behaviors are beneficial or detrimental to their career development. One example is "I try to model my behavior after my mentor" (Scandura \& Ragins, 1993, p. 257). Role modeling involves the feeling of mutual respect between a mentor and protégé (Kram, 1985).

1. This document is AEC740, one of a series of the Department of Agricultural Education and Communication, UF/IFAS Extension. Original publication date November 2021. Visit the EDIS website at https://edis.ifas.ufl.edu for the currently supported version of this publication.

2. Amy Harder, professor, and Savanna Turner, doctoral candidate, Department of Agricultural Education and Communication, UF/IFAS Extension, Gainesville, FL 32611.

The Institute of Food and Agricultural Sciences (IFAS) is an Equal Opportunity Institution authorized to provide research, educational information and other services

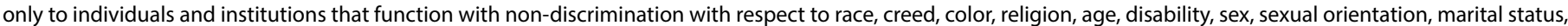

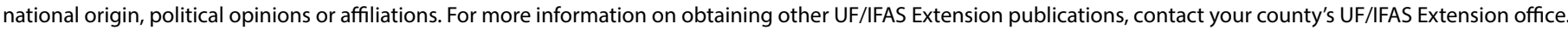
U.S. Department of Agriculture, UF/IFAS Extension Service, University of Florida, IFAS, Florida A \& M University Cooperative Extension Program, and Boards of County Commissioners Cooperating. Nick T. Place, dean for UF/IFAS Extension. 
The combination of the three functions of the mentoring relationship can be complex. Mentors and protégés growand change through the experience in various ways. For mentors, the benefit of a mentoring relationship is empowerment. They have the capacity to support and foster an environment that can open doors for mentees. Mentors can also transmit skills that enhance protégés' capacities, which can support personal growth and satisfaction with a career (Kram, 1983). For protégés, the benefits of a mentoring relationship should be higher job satisfaction, more organizational commitment, and less turnover for positions (Raabe \& Beehr, 2003).

\section{The Mentoring Calendar}

A 2021 study by Harder et al. found early-career Extension agents had significantly more positive perceptions of their mentoring relationships when their mentors contacted them at least 2-3 times a month. Mentors have multiple responsibilities beyond their service in that role, so planning can help make mentoring a more enjoyable and manageable commitment. Further, planning allows mentors to intentionally focus on performing the three mentoring functions.

An example of how to intentionally plan mentoring is provided in Table 1. Specific examples are included that align with historically important dates, such as conference submission season, the annual Extension Professional Associations of Florida (EPAF) conference, and reporting season. For each topic listed, the corresponding mentoring function has been marked, which allows a mentor to ensure a balanced approach to addressing the three functions.

A few guidelines may be useful to consider when creating a mentoring calendar.

- What's going on programmatically during the time frame being planned? What organizational events or deadlines are coming up? Strategically address those.

- Each month should include at least one focused effort on psychosocial support; early-career agents across three states, including Florida, were least likely to agree their mentors performed this function (Harder et al., 2021).

- Collaborate with peers to generate content; ask unit leaders for ideas too.

- Ask to be added to the Extension Mentor listserv (contact Tyann Haile, thaile@ufl.edu). Resources and ideas for discussion with protégés are emailed monthly and include suggestions for each mentor function.
- Set calendar appointments to contact protégés; mentoring is a commitment and having it on a calendar helps protect time to uphold that commitment.

\section{Conclusion}

This publication focused on defining the three functions of a mentor and provided a template for planning mentor activities. For a brief overview of related mentoring EDIS publication, please see Appendix A.

\section{References}

Harder, A., Narine, L. K., Benge, M., Denny, M. D., \& Farner, K. (2021). Exploring early career extension agents' perceptions of their mentors, best liked co-workers, and organizational commitment. Journal of Human Sciences and Extension, 9(2), 80-95. https://www.jhseonline.com/article/ view/1162/909

Kram, K. (1983). Phases of the mentor relationship. The Academy of Management Journal, 26(4), 608-625. https:// doi.org/10.5465/255910

Raabe, B., \& Beehr, T. A. (2003). Formal mentoring versus supervisor and coworker relationships' differences in perceptions and impact. Journal of Organizational Behavior, 24, 271-293. https://doi.org/10.1002/job.193

Scandura, T. A., \& Ragins, B. R. (1993). The effects of sex and gender role orientation on mentorship in maledominated occupations. Journal of Vocational Behavior, 43, 251-265. https://doi.org/10.1006/jvbe.1993.1046

\section{Appendix A: Related EDIS Publications about Mentoring}

Using Mentoring as a Part of Professional Development

This EDIS publication defines mentoring, give a brief history, and review the stages of the mentoring process. It also highlights the benefits mentors, protégés, and organizations can expect from the utilization of a mentoring process.

\section{UF/IFAS Extension Mentoring Roles and Responsibilities}

This publication provides information about the mentoring roles and responsibilities of protégés, County and District Extension Directors, and the state Extension specialist.

\section{Developing a Mentorship Program in Higher Education Institutions}

This publication defines mentorship, explains the value of mentorship, and describes how mentoring programs can be established. 
Table 1. Example of a Mentoring Calendar by Mentoring Function.

\begin{tabular}{|c|c|c|c|c|}
\hline Date & Topic & $\mathbf{R M}^{\mathbf{a}}$ & $\mathrm{CD}^{\mathbf{b}}$ & PS \\
\hline Aug. 4 & Invite your protégé to work on a project, conference submission, or program with you. & & $\mathrm{X}$ & \\
\hline Aug. 18 & $\begin{array}{l}\text { Check in to see how the transition from summer to fall is going; this can be a stressful time of } \\
\text { year as personal and professional activities tend to occur more frequently. }\end{array}$ & & & $\mathrm{X}$ \\
\hline Sept. 1 & $\begin{array}{l}\text { What to expect at EPAF; address any concerns; provide guidance on how to intentionally use } \\
\text { the time at EPAF for career development. }\end{array}$ & & $\mathrm{x}$ & $\mathrm{X}$ \\
\hline EPAF & $\begin{array}{l}\text { Set a positive example with your own engagement (attire, attendance). Watch your protégé } \\
\text { present; have a meal together; invite to social time; sit together at a session. }\end{array}$ & $\mathrm{x}$ & & $\mathrm{X}$ \\
\hline Oct. 6 & $\begin{array}{l}\text { Encourage your protégé to apply for at least one award in the coming year. Be specific in } \\
\text { your encouragement-what do you know about their work that you think is worthy of } \\
\text { recognition, or could be by the time awards are due next year? }\end{array}$ & & & $\mathrm{X}$ \\
\hline Oct. 20 & $\begin{array}{l}\text { Help your protégé find resources that will improve their program development and } \\
\text { evaluation competencies by showing them what's available at pdec.ifas.ufl.edu. }\end{array}$ & & $\mathrm{X}$ & \\
\hline Nov. 3 & $\begin{array}{l}\text { Send your protégé a quick note describing at least one reason you are thankful to be their } \\
\text { mentor. }\end{array}$ & & & $\mathrm{x}$ \\
\hline Nov. 17 & $\begin{array}{l}\text { Share your ROA/Workload reports as examples for your protégé, or ask your unit leader for an } \\
\text { example to share. }\end{array}$ & $\mathrm{x}$ & & \\
\hline Dec. 1 & Provide encouragement for year-end reporting; answer last-minute questions. & & & $\mathrm{x}$ \\
\hline Dec. 15 & $\begin{array}{l}\text { Model personal and professional balance; discussion plans for year-end rest with your } \\
\text { protégé. }\end{array}$ & $\mathrm{x}$ & & \\
\hline \multicolumn{5}{|c|}{$\begin{array}{l}\text { a Role modeling. } \\
{ }^{b} \text { Career development. } \\
{ }^{c} \text { Psychosocial support. }\end{array}$} \\
\hline
\end{tabular}

